\title{
ㄴ․…
}

\author{
「医学に貢献するレーザー計測および診断技術」 \\ 解説小特集号によせて \\ 田代 英夫 \\ 理化学研究所 工学基盤研究部 ( \%351-0198 埼玉県和光市広沢2-1)
}

\section{Possible Contribution of Laser Technology to Medical Diagnosis and Treatment}

\author{
Hideo TASHIRO \\ RIKEN (The Institute of Physical and Chemical Research) Advanced Engineering Center
}

2-1 Hirosawa, Wako, Saitama 351-0198

(Received February 8, 2000)

光を使ってX線や超音波のように生体内をみるというの は光研究者, 光技術者の夢であり, ミレニアムを迎えて挑 戦すべき分野の一つであることには間違いはない．生体 の光観測というと有名なデモンストレーション,すなわち 近赤外光を使って撮った手掌の透過像を見て光CTの可能 性を直感した人も多いであろう。光による非侵襲の血糖 值測定をめざして挑戦してきた研究者・技術者も少なく ない. また, 蛍光発光によってガン化した細胞の早期検出 が可能と主張する研究も多々ある。しかしながら,レー ザーメス, レーザー結石破壊, 光力学治療など光エネルギー を直接用いたレーザー光医療と比べると, 光計測・診断技 術の医療の現場への貢献度はまだまだ低いと認めざるを 得ない. レーザーによる分光解析能, 時間分解能は生体と いう多成分の散乱系において実用的には無力なのであろ うか. レーザー光源, 高感度検出器の充実, 散乱体中での ミクロービア・ランベルト則を使った計測理論をもって しても道は半ばなのだろうか. X線や超音波など既に土俵 に上がっている技術の着実な進歩に本当に光技術で対抗 できるのだろうか. そんな心配も湧き上がってくる．し かし, 一方, レーザーを使った医療診断器としてOCT (Optical Coherence Tomography) は着実な普及をみせている し, しかも心強いことにその元は日本にあるともいえる.

激しい開発競争の中で, 2003年の終了目標も早まる勢い のゲノムプロジェクトを見越して, ポストゲノムのテーマ 検討に世界は一斉に走り出している。米国は,ゲノムプロ ジェクトの成果を実際の医療分野に生かす新たな国家戦 略として“医用光学”を重要課題のひとつとすることを決定 している。これは, ゲノムに代表される分子生物学の成果 をふまえつつ, 非侵襲的な新しい診断法(特に早期診断)の
開発を中心に据えている. 現代医療においてはQuality Of Life $(\mathrm{QOL})$ の重要性が一層強調されるようになり, 臨床で 患者が受ける不安や苦痛という個人レベルでの負担の軽 減が求められており, また検査試薬などにかかる医療費増 加や, 医療環境污染など, 社会レベルでの負担の低減も社 会的要請である.このため, 新しい医療技術への期待も大 きい.

光は本当にどんな医療技術として役に立つのか. 診察 から治療におけるプロセスで非侵襲で試薬や容器のほと んどいらない光観測技術を実用化することによって, 個 人・社会の負担を最小限に押さえることのできる新しい 医療技術の構築が課題である。目標の設定とそれに必要 な基礎研究, 分光デー夕の充実と, さらに医療用の要求を みたすエンジニアリングを磨けば光は本当に医療に役に 立つものとなるはずである. 本特集は, 光によってX線や 超音波ではできない, ファンクショナルな診断すなわち分 光解析によって, 単なる形態的な異常ではなく病変の実態 の観測, 例えばその腫瘍は良性なのか悪性なのか, X線等で 見える影の実体は腫瘍細胞かそれとも単なるタンパクの 塊なのか, また組織のバイアビリティ,つまり酸素消費は 正常值であるか, あるいはマクロファージの存在を示す NO 分子等が出ていないかなど, 光の特長を生かした究極の診 断技術を目指すことができるはずである。本特集では,こ のような視点で, レーザーを使った機能性診断, 光感受性 物質によるイメージング, 生体卜モグラフィー, 赤外レー ザーによる分子手術, 医療計測要求に答えるべきレーザー, 光による実際の病態診断について, 最前線の研究者に執筆 していただいた.メディカルフォトニクスの分野の研究 のさらなる活性化の一助となれば幸いである. 